\title{
From Isolation to Violence: Changes of the Domestic Environment in the Iranian Family under COVID-19*
}

\author{
Svetlana Bankovskaya \\ PhD, Professor, Leading Research Fellow, Centre for Fundamental Sociology, HSE University \\ Address: 20 Myasnitskaya Str., Moscow, 101000, Russian Federation \\ E-mail: sbankovskaya@hse.ru
}

Javad Maddahi

$\mathrm{PhD}$ in Sociology of Social Problems, Kharazmi University Address: No. 43, Shahid Mofatteh Ave., Tehran, Iran

E-mail: std_Javad.Maddahi@khu.ac.ir

Tahere Lotfi Khachaki

PhD Economic \& Developmental Sociology, Ferdowsi University of Mashhad Address: Azadi Square, Mashhad, Razavi Khorasan Province, Iran

E-mail: ta_lo249@mail.um.ac.ir

\begin{abstract}
Domestic violence became a worldwide social problem during the outbreak of the COVID-19 pandemic, especially during the period of lockdown. It has been also experienced in some Iranian families examined in our research. The article presents the data obtained by semistructured interviews and draws some (so-far tentative) conclusions about the nature of the changes in the regime of relations of the traditional Iranian family, including the intensification of domestic violence, and the prevailing mental/emotional violence. Among the variety of nuances in the types of violence, some of them are already well classified, such as symbolic, physical, and economic. Other manifestations of domestic violence are humiliation and verbal violence, the intensification of restrictions on (or even the interrupting of) a woman's relationship with her friends and acquaintances by her husband; the husband's violence against their children; disputes over the observance of health tips during the quarantine period, and the intensification of religious conflicts during the period of home quarantine need further study and interpretation. As theory-oriented research, it involves the study of the relationship of various types of violence, starting with the newest ones of self-violence and self-isolation, and getting through the modifications of already-known types of violence which are caused by the first type.
\end{abstract}

Keywords: domestic violence against woman, COVID-19 lockdown, perception of «home», emotional violence

\section{Introduction}

Domestic violence as a pervasive and enduring problem was the subject-matter of various studies long before the pandemic of COVID-19. According to a World Health Orga-

* The results of the project "Ethics of Solidarity and the Biopolitics of Quarantine: Theoretical Problems of the Cultural and Political Transformations during Pandemic", carried out within the framework of the Basic Research Program at the National Research University Higher School of Economics (HSE University) in 2021, are presented in this work. 
nization estimate, approximately 1 in 3 women globally are subjected to physical and/or sexual violence by an intimate partner in their lifetime (UN Women, 2021a). Different policies enacted by governments world-wide, such as stay-at-home requirements or lockdowns, were meant to reduce the spread of the COVID-19 virus; yet, they may also have exacerbated the problem. This effect becomes particularly evident when the coronavirus pandemic intersects with the pandemic of domestic violence against women.

Dr. Tedros Adhanom Ghebreyesus, WHO Director-General, stated that "Violence against women is endemic in every country and culture, causing harm to millions of women and their families, and has been exacerbated by the COVID-19 pandemic," adding "But unlike COVID-19, violence against women cannot be stopped with a vaccine. We can only fight it with deep-rooted and sustained efforts - by governments, communities and individuals - to change harmful attitudes, improve access to opportunities and services for women and girls, and foster healthy and mutually respectful relationships" (Ibid.).

Various women's organizations have reported a significant increase in cases of violence against women during the COVID lockdowns. Still, the collection of detailed data of these cases was impeded by the sensitivity of the issue, the stigma and shame around the subject, as well as by definite constraints imposed by the changes in habitual life during the pandemic. The numbers vary across countries and demographics, but overall, the pandemic has increased women's exposure to violence and diminished their feelings of safety.

We owe COVID, beyond other things, the spread of the term "self-isolation", or even "self-imprisonment". The place of self-isolation is often the home, which, along with the function of a safe, personal, cozy refuge, acquires the function of a prison. This transformation of the "home" into the category of what Derrida coined as "undécidables" (Derrida, 1994) (home and prison simultaneously, and neither completely home nor prison at the same time) is due not only to a change in the spatial regime crossing the boundaries of the home. The marginalization of the routine place is caused also by the change in relations between the inhabitants of the household and their changed attitudes towards the traditional domestic rights, which could be only partly explained by the compaction of space and tightness of these relations. These changes are likely to be most noticeable and sensitive where any changes are least welcomed, that is, in the traditional family where they generate mostly negative reactions.

As UN Women Executive Director Phumzile Mlambo-Ngcuka noticed, "We know that the multiple impacts of COVID-19 have triggered a "shadow pandemic" of increased reported violence of all kinds against women and girls" (UN Women, 2021a).

Still, the data on COVID cases collected by numerous organizations are not very often informative as to violence against women, since they are not sex and age disaggregated. Thus, while WHO collects COVID-19 cases and deaths data from member states, only 41 out of 236 countries, areas or territories (17\%) reported sex-disaggregated data for at least 95\% of cases between January, 2020, and April, 2021. Additionally, 72 countries (30\%) reported sex-disaggregation for at least $70 \%$ of cases. Globally, sex-disaggregated data were 
reported for over a half of all cases (51\%) (WHO, 2021). Moreover, the situation is exacerbated by the fact that official national statistics on different forms of violence against women and their particularly aggravated condition under COVID is not available (this is also the case of Iran) (UN Women, 2021b).

Besides, however valuable even disaggregated data may be, they can only give a very general picture of the phenomenon of "domestic violence" without specifying the emergence of new varieties at a particular point in time and place. The research problem is therefore to adjust or supplement the statistical background with the specific qualitative data indispensable for further research of the domestic violence issue.

Thus, our research aims at providing timely evidence about the impact of the COVID-19 lockdowns on female experiences of physical and mental domestic violence in the Iranian family. Particular attention is paid to the detailed detection and description of the types of physical and mental violence, as well as on their impact on inter-marital relationships.

\section{Local/Country Context}

Iran is an upper-middle income country with a population of 82.91 million, with $1,566.83$ COVID-19 deaths per million as of December 2021 (Statista, 2021).

The specific situation created by the lockdown of some Iranian families requires special attention from social scientists and makes research into the changes in traditional family patterns as well as domestic violence particularly relevant. Domestic violence in Iran has been constantly studied in different ways and with different interpretations: these works include studies of domestic violence in cities, the abuse of local women, the risk factors of domestic violence featured for Iran, and others (see Ghazizadeh, 2005; Mousavi, Eshagian, 2005; Rasoulian et al., 2017; Rahmatian, Hosseini, 2015; Ghahari et al., 2008; Amanoolahifard et al., 2008; Malek Afzali, 2004).

The recent Iranian research on domestic violence against women (Zamani-Moghadam, Hasanvandi, 2019; Maghsoudi et al., 2015; Zare Shahabadi, Nadarpoor, 2016) and other similar studies show domestic violence against women to be present in some Iranian families. The prevalence of the COVID-19 pandemic and the lockdown experience account for the increase of domestic violence, at least in some families. The results of national opinion polls in Iran support this view; inter-marital tensions show a $15.8 \%$ increase during the COVID-19 pandemic period from April 12, 2020, to April 15, 2020. People were asked, "Disagreements and quarrels have increased in some families during the lockdown. Was it a problem in your family?". The majority of Iranians, $84 \%$, stated that there were not many fights and lawsuits in their family due to staying at home; $15.8 \%$ said there were disputes, fights, and lawsuits in their family, while $0.2 \%$ did not answer this question. ${ }^{1}$

\footnotetext{
1. http://ispa.ir/Default/Details/fa/2177/
} 
If we take the statistical data mentioned above into account, it could be inferred that we actually deal with those (at least) $15.8-16 \%$ who reported having "disputes, fights and lawsuits in their family" in our research. Statistics, however, do not reveal the features of the phenomena; for example, do the respondents perceive and identify those "disagreements and quarrels" as "violence" at all? However, taking the challenge to specify, detail, and elaborate what exactly is meant by "violence", whether we can refer to these $16 \%$ as to participants in violence, what kinds and nuances of it could be discerned, and what kinds of strategies are used to produce this phenomenon, we need to get immersed into the very data on domestic violence and to develop our account from these data. Thus, we arrive at the research methodology of the grounded theory.

\section{Data and Methodology}

If the goal is to understand an environment that is less well-known or has not been clearly explored in the past, as J. Morse and L. Richard (2002) argue, it is reasonable to use the grounded theory approach. Our study also needs to understand a new environment of domestic violence under COVID-19 which is not sufficiently understood, and has not been studied in the past since the circumstances of COVID epidemic are novel; their effects on different areas of social life have not been studied in detail yet and are unpredictable. The grounded theory methodological focus on "discovering of theory from data systematically obtained and analyzed in social research" (Glaser, Strauss, 1967: 1) makes it quite suitable for the study of (allegedly) novel forms of domestic violence, for tracing out its trends under COVID-lockdown conditions and depicting its consequences for the marital/domestic relationship in the specific context of the Iranian family.

In our study, we adhere mainly to the Straussian version of the grounded theory with just one deviation to the Charmazian version: while in the Straussian version, local issues are explored so as to then generalize in a broader context, the Charmazian version is aimed to explore local issues for the local context explication (Charmaz, 2006).

The primary data analysis technique according to this method (the Straussian version) is coding (a three-step process with three different forms, those of open coding, axial coding, and selective coding (Ostvar Namaghi, 2006; Strauss, Corbin, 1994: 22-23; Glaser, 2014). In open coding, concept-units were identified and inferred from the transcripts of interviews, then grouped into categories according to their similarities. During axial coding, categories were related to each other to obtain a more detailed picture of the phenomenon via Constant Comparative Data Analysis. In our study, we used the five-component paradigmatic model of the Straussian grounded theory: the context - in what circumstances (of time and place) the phenomenon appears (domestic violence by the definition has as its place home); the causal condition - the various events or occurrences provoking the development of a phenomenon; the intervening condition - effecting the causal conditions of the phenomenon so as they may facilitate, hinder, or even restrict the strategies adopted; the strategies - the actions performed to achieve the phenomenon, and the consequences - the actions/interactions sustaining the phenomenon 
under study. In the selective coding stage, various inter-weavings and interconnections between these five components are organized around the central category of "domestic violence under lockdown" (Flick, von Kardoff, Streinke, 2004).

The main result of the grounded theory method implementation is a theory/idea/hypothesis on the studied phenomenon account, derived from the data analysis drawn from three-step coding and the Constant Comparative Data Analysis. In our case, this is the issue of domestic violence under specific circumstances; the first is the COVID lockdown and the second is the Iranian domestic background.

The data for our phenomenon under study was collected in the city of Chalus in the Mazandaran province located in the north of Iran and is based on 22 semi-structured interviews among women subjected to violence during COVID-19 isolation.

Informal interviews were initially used in the study to develop the concept-units. After a few initial interviews, adjustments were made to the interview questions to better assess the research phenomenon, and the categories derived from the initial interviews were followed up in subsequent interviews.

\section{The Sample ${ }^{2}$}

The criteria for the sampling included being female, being married, having been married for at least three months, and sharing a house with a spouse/an intimate male partner.

The interviews were conducted with women who had appropriate and relatively sufficient knowledge of the subject under the study or an aspect of it. ${ }^{3}$ As we sought to explore the phenomenon of violence in these interviews, we generally approached women who were either already aware of the occurrence of violence in their family environment (such as friends and acquaintances) or have had a personal experience of violence (in their mind). After the initial interviews, the "snowball" sampling provided us with access to the respondents that were their friends or acquaintances who had similar conditions in terms of domestic violence. Since we have purposefully identified families which have experienced domestic violence in the COVID lockdown period via a snowball sampling, we do not seek to extrapolate the results to all Iranian families.

\section{The Procedure of Interviewing}

The duration of the interviews was 2 to 3 hours, and the interviews were conducted online, via social networks such as WhatsApp and Skype, or by telephone (depending on the respondent's choice), due to the prevalence of the COVID-19 virus. In a few cases, the interview was conducted in person.

2. For the complete list of respondents, see Appendix 1.

3. While many surveys on violence against women focus specifically on women of the reproductive age (15-49), our findings reveal that we can get valuable insights also from older women (Robabeh, 52 years old, and Sedighe, 66). The evidence which can be inferred from the research results is that age does not protect from violence. 
The time of the interview was chosen by the respondent and, in some cases, the interview was conducted more than once and at intervals determined by the respondent.

Respondents usually chose the time for the interview themselves, like when their spouse/partner was not at home so to have complete freedom to talk. Respondents were reassured that the information on their identity was protected, and that pseudonyms were used in the research. Interviews were recorded in handwriting during the communication, or immediately after the interview, and, in the rare cases when the respondent allowed us to record her voice, the audio was recorded. ${ }^{4}$

We continued interviewing until we reached theoretical saturation, ${ }^{5}$ which means that the analysis of data reached such a point that sampling more data will not lead to more information related to the phenomenon under research. In a definition by J. Morse (2004: 1124), "theoretical saturation" refers to "the phase of qualitative data analysis in which the researcher has continued sampling and analyzing data until no new data appear and all concepts of the theory are well-developed ... and their linkages to other concepts are clearly described".

Although the researchers have still not agreed on a rigorously verified method of identifying "how much is enough", we sought to adhere to Morse's recommendation that qualitative researchers (grounded theory theorists included) use certain strategies to achieve data saturation and rigor such as "prolonged engagement, persistent observation, and thick, rich description; inter-rater reliability, negative case analysis; peer review or debriefing; clarifying researcher bias; member checking; external audits, and triangulation" (Morse, 2015). One of the significant factors that influence the researchers' decision to stop data collection at data saturation is the factor of the sample. This factor also guided our understanding of theoretical saturation: homogeneous and experienced participants in the research topic need fewer interviews and may reach saturation faster than a heterogeneous sample with less-experienced participants.

Although we managed to achieve theoretical saturation during the 14 interviews, ${ }^{6}$ we increased the number of interviews up to 22 for a more reliable data analysis. Although the questions were related to the domestic situation during the outbreak of the COVID-19 pandemic, the challenges that women face in their marital relationships, the manner/type of violence, the very perception of violence and so on were perdurable to some extent.

4. It became usual for the survey practices to stress that telephone interviews invoke multiple challenges and limitations (see, for example, Tourangeau, Yan, 2007) people are known to underreport when directly asked about sensitive topics, respondents might not have enough privacy to answer questions sincerely, especially in overcrowded homes, inability over the telephone to see visual signs of distress and body-glosses, finally, asking questions about domestic violence may pose for already stressed individuals more strain that requires a response from the interviewer. Still, under the COVID-19 regulations distant forms of interviewing seem to be more welcomed than none at all.

5. For the critical discussion on the concept, see, for example, Aldiabat, Le Navenec, 2018; Bowen, 2008; Guest, Bunce, Johnson, 2006; O’Reilly, Parker, 2012.

6. "Meaning saturation" in terms of Hennink, Kaiser, and Marconi (2016) can be reached in 16-24 interviews. Guest, Bunce, and Johnson in "How Many Interviews are Enough? An Experiment with Data Saturation and Variability" (2006) indicate that data saturation can be reached with the first twelve interviews. 
After the interviews were transcribed, they were analyzed through three stages of open, axial, and selective coding to get an idea on the central category and supporting categories. In this study, while making the necessary efforts to ensure the number of interviews to achieve theoretical saturation, we tried to increase the validity of the research by the method of "validation through members", asking the respondents' opinions about the findings and interpretations made by the researcher. For this purpose, the findings of the interview were delivered to the respondents and corrected taking into consideration their opinions after the end of each interview.

\section{The Framework of Analysis and Results}

On the whole, the obtained results of the three-stage coding revealed that the consequences of the stay-at-home policies under COVID-19 were particularly severe for psychological/emotional/mental well-being. It is a paradox of sorts that ensuring physical health security entails emotional problems and feelings of insecurity. The very isolation and encapsulation of women in their houses upended their lives and put them under stress not only for their physical well-being. Their exposure to physical violence was compounded by violent emotional impacts that made their stay at home much worse.

According to the recent UN Women survey which covered 13 countries across the world, the most widespread form of violence is verbal abuse $(50 \%)$, followed by sexual harassment $(40 \%)$, physical abuse $(36 \%)$, denial of basic needs $(35 \%)$, and the denial of the means of communication (30\%). Seven in 10 women surveyed believe violence against women is common in their community (UN Women, 2021c).

Women who reported direct or indirect experiences of violence and feeling unsafe at home in pre-COVID times are more likely to say that COVID has worsened their feelings of stress and anxiety (as to the UN Women survey, 2021); moreover, they also experience the inability to stop worrying, being afraid, and a lack of interest in doing things. The main type of violence under lockdown reported by women was emotional abuse $(80.8 \%)$; the rate of this type was always higher than other types of abuse (Rasoulian et al., 2017: e4280).

The findings of our study (in the Iranian family context) support the general statistics tracing the predominance of emotional/mental violence in domestic violence in general. However, just as with statistics on domestic violence in general, statistics on emotional/ mental violence do not reveal a specific picture of this type of domestic violence, such as its local nature, its dynamics in the particular setting of the COVID lockdown, or its long- or short-term consequences on the relationships of those involved.

The overall frame of reference resulted from the coding and grounding the main idea of the research is presented in the Figure 1.

The account of the data analysis can start with the external (in relation to family/ household) prerequisites of domestic violence such as the COVID lockdown, and proceeds to the inner altered-relationship that finally arrives at violence (physical or mental) ${ }^{7}$

7. For the source of theoretically calibrated violence typology see: Galtung, 1969, 1990. 


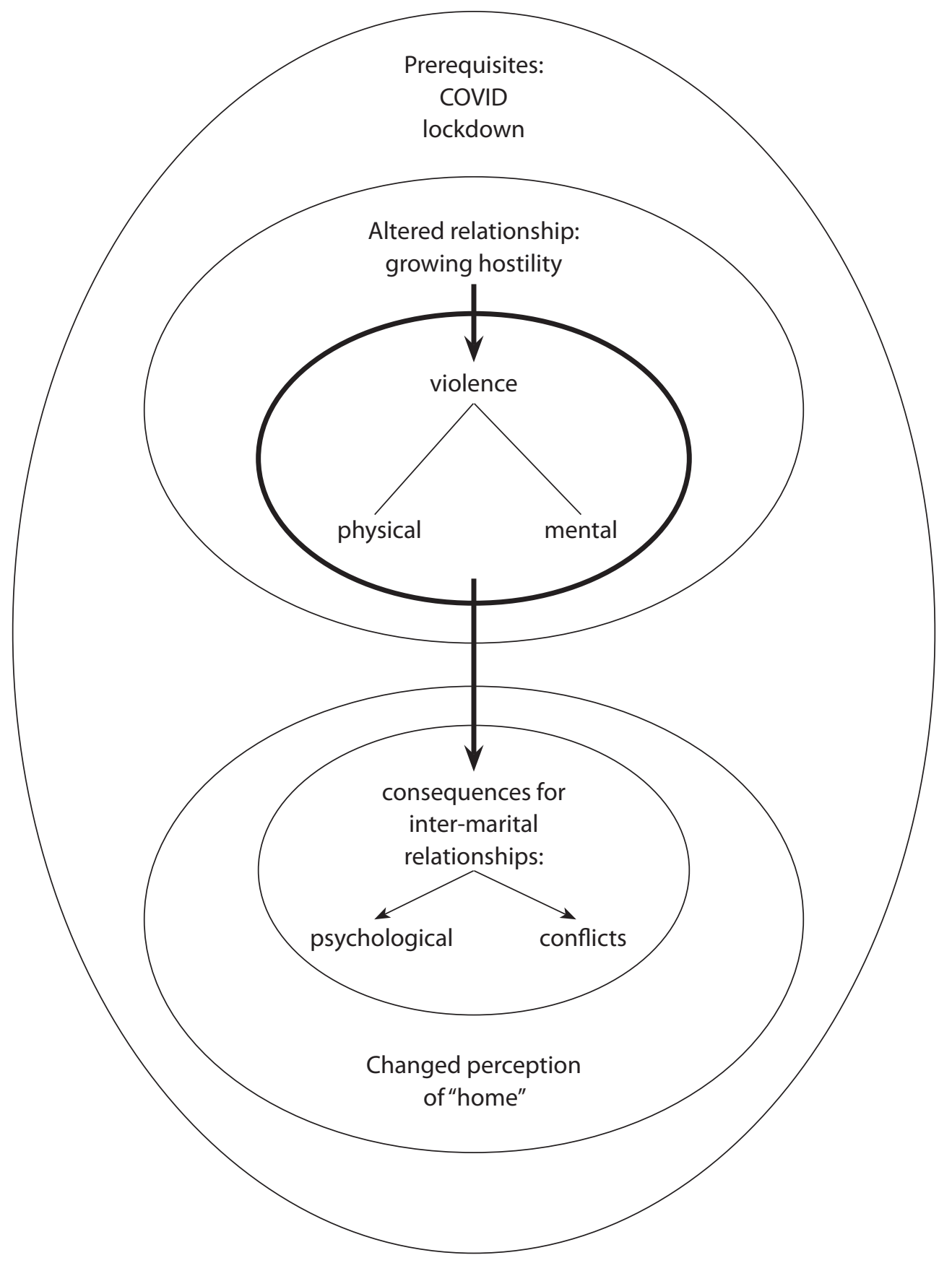

Fig. 1. Domestic violence under the COVID19 lockdown in Iranian families (and its consequences for inter-marital interactions) 
that also has long- or short-term consequences for the inter-marital relationship (which can be deep psychological or enacted conflicts) known as "home".

The main types of violence in the emotionally stressful situation at home are the growing hostility, the frustration in trying to set up a sanitary, safe habitat, the emotional abuse, and humiliation, all having serious consequences for the inter-marital relationship. Thus, the emotional/mental violence (as to Figure 1) resides in a "growing hostility" as the altered relationship, in "mental/emotional violence" per se (as a momentary act), and in the "psychological consequences for inter-marital relationships". They revealed concept-units that grounded the developed idea of the framework of analysis for domestic violence (under COVID lockdown in Iranian families) as shown in Figure 1, as well as the prevalence of mental/emotional violence. The concept-units are as follows:

\section{Altered inter-marital relationship - growing hostility:}

For the man, it is leaving home, with an indifference to the responsibilities and a deliberate disregard for social distance; a lack of personal hygiene and not paying attention to the coronavirus; the preference of male friends over the spouse and children; the man's lordly encounter with his wife at home; the lack of hygiene by the man as a weapon to harass the woman; the observance of hygienic conditions provided that the woman is completely obedient at home; cutting ties with the family and leaving the woman alone to take care of the children; the man's lack of cooperation in domestic affairs, despite not going to work; the man's lack of cooperation in handling the care for children; increasing female household chores due to food disinfection and healthier food preparation; challenges due to spousal irresponsibility and selfishness; and by reducing women's economic authority during the quarantine period.

\section{Violence:}

Physical: beating, sexual harassment, forcing and pressuring a woman to have sex, slapping, or throwing a cell phone at a spouse, bruising the wife's hand; putting a woman under house arrest and the shopping is done by a man; does not allow the woman to leave the house even for a few minutes; the husband's violence against their children.

Mental: restrictions on a woman's relationship with her friends by her husband, interrupting a woman's relationship with her friends and acquaintances, controlling women's activities in cyberspace with the presence of more men at home during the quarantine period; female ridicule for a fear of coronavirus, the husband's obscenities and verbal abuses, abuse with corona virus content, constant outbursts of anger at a woman's usual behavior at home, the husband's objections and unreasonable abuses, the threat of violence, threatening a woman with divorce, or the demand of obedience and servitude.

\section{Consequences for the inter-marital relationship:}

Psychological: emotional distancing; the decision to divorce after Coronavirus, a distrust of the spouse; fear and anxiety caused by the coronavirus; increased anger and resentment of the man due to financial pressure and its transfer to the spouse. 
Conflicts: Reminder of previous family disputes caused by the man; religious conflicts and their escalation; the previous disputes over the families of the parties are highlighted; transferring male and female conflicts to the children in the family; increased economic disputes between the husband and wife due to male unemployment during the lockdown period, and the assignment of home expenses management from the woman to the man and then arguing for this reason.

See the detailed distribution of the coding results of violence concept-units by the pivotal and comprehensive codes/categories accompanied by the interview cases' citations in Appendix 2.

The idea/theory which could be inferred from the data analysis in our research is that domestic violence under lockdown turns a home from a "shelter" into a dangerous place to stay (or at least adds this quality to "home").

How does it happen, or, rather, proceed to this outcome?

Lockdown as a prerequisite means, above all, the prolonged (offbeat) co-presence on a delimited space of home, and, consequently, the change in the temporal/spatial experiencing of interactions between family members, or those experiencing intimacy.

This kind of co-presence entails a change in intimacy (as it is understood as a feature of a primary group) regime of more-than-usual dense everyday interaction, and fewerthan-usual opportunities for distancing in the case of emergency.

The surplus of forced intimacy makes for more-than-usual frequency of emotional strain, abuse, frustration, quarrels, slurs, accusations, etc., that is, growing hostility, to summarize.

Growing hostility cumulates into emotional/mental violence, which in contrast to physical violence (instantaneous event/act) is prolonged in its nature; it is a process of pressure, bullying, ridicule, etc., which creates an atmosphere of violence (which in turn can provoke physical violence as well).

The atmosphere of emotional violence at home (or at least, the addition of this kind of mood to the home milieu) turns it into the kind of a heterotopia; it is now not a refuge, or "sweet home", or a shelter, etc., but an undesirable and dangerous place to stay.

Some consequences of staying in such a domestic environment are not hard to anticipate, such as the change in the marital relationship that threatens its sustainability and can even end in divorce (the possibility of this outcome is backed up by the data obtained from the interviews).

Why is this theory derived as a grounded theory, and dependent on the nature and content of the empirical data? If the central category/phenomenon is "domestic violence during lockdown", the unknowns are specific cases of this violence in the particular setting of the Iranian family under lockdown. As data is collected and openly coded, we get a range of categories that further on (by axial coding) give us comprehensive categories of "emotional/mental violence", that is dominant in relation to "physical violence" (this 
could have been only inferred from the data). The iteration of the interviewing (going back to the respondents' accounts of the acquired idea for the "emotional violence" category) gives evidence that "emotional violence" has been experienced as a prolonged process, a sort of "liquid violence", and is associated strongly with the space of home.

Categories (comprehensive codes as the result of selective coding, see Appendix 2) of "emotional violence" are: humiliation and verbal abuse; psychological violence; performing male domination and restrictions on women; the challenge focusing on the spouse's family; irresponsibility and carelessness at home; disputes over the observance of health tips during the lockdown period, and the intensification of religious conflicts during the period of lockdown.

These categories were used to refine and specify "emotional/mental violence" in the second iteration of interviewing. As an outcome of the open coding, the specified emotional/mental violence' concept-units list of emotional/mental violence' categories was created (see Appendix 3).

\section{Conclusion}

Findings inferred from our study show an increase in domestic violence (psychological/ mental and emotional particularly) since the beginning of the COVID-19 stay-at-home requirements. The main outcomes of the study could be summed up in two findings. First, a detailed account of emotional/mental violence in Iranian families/homes during (and due to) COVID-19 lockdown was presented. The list of these categories can become the background for the further emotional domestic violence study since the very list could be refined and developed according to the local environment. Second, the idea of the reference between emotional/mental violence and the transformation of the "home" notion and perception was proposed for further development.

It must be said, however, that these interviews do not reflect the situation of the Iranian family in general. In many Iranian families, especially of the middle and upper class where women have access to educational and supportive resources and facilities, there is dialogue, interaction, and a relatively equal relationship. These interviews are about families with a history of domestic violence against women by men, and we do not seek to generalize the results to all Iranian families.

However, we consider that the results of this research provide a viable solution to the problem of missing information on domestic-violence sensitive topics during the COVID-19 pandemic. 
Appendix 1. The List of Respondents ${ }^{8}$

\begin{tabular}{|c|c|c|c|c|c|}
\hline № & Name & Age & $\begin{array}{l}\text { Employment } \\
\text { status }\end{array}$ & $\begin{array}{c}\text { Duration of } \\
\text { marriage in years }\end{array}$ & $\begin{array}{l}\text { Number of } \\
\text { children }\end{array}$ \\
\hline 1 & Mina & 28 & Unemployed & 2 & 1 \\
\hline 2 & Golnaz & 30 & Unemployed & 5 & 1 \\
\hline 3 & Nazanin & 31 & Unemployed & 2 & 1 \\
\hline 4 & Robabeh & 52 & Unemployed & 30 & 3 \\
\hline 5 & Parisa & 32 & Unemployed & 8 & 1 \\
\hline 6 & Fereshteh & 46 & Unemployed & 20 & 2 \\
\hline 7 & Susan & 29 & Unemployed & 4 & 1 \\
\hline 8 & Nahid & 27 & Unemployed & 3 & 1 \\
\hline 9 & Nazi & 38 & Unemployed & 15 & 1 \\
\hline 10 & Sara & 36 & Unemployed & 10 & 1 \\
\hline 11 & Fatemeh & 38 & Unemployed & 17 & 1 \\
\hline 12 & Negar & 47 & Unemployed & 20 & 2 \\
\hline 13 & Neda & 28 & Unemployed & 3 & 0 \\
\hline 14 & Sanaz & 39 & Unemployed & 9 & 2 \\
\hline 15 & Robabeh & 24 & Unemployed & 2 & 1 \\
\hline 16 & Samaneh & 39 & Unemployed & 12 & 1 \\
\hline 17 & Nastaran & 25 & Unemployed & 1 & 2 \\
\hline 18 & Negar & 39 & Unemployed & 4 & 2 \\
\hline 19 & Sogand & 33 & Unemployed & 4 & 1 \\
\hline 20 & Sedighe & 66 & Unemployed & 41 & 5 \\
\hline 21 & Mobina & 45 & Employed (tailor) & 30 & 3 \\
\hline 22 & Soodabeh & 31 & Unemployed & 3 & 0 \\
\hline
\end{tabular}

8. For ethical reasons and to preserve anonymity, pseudonyms are used to list respondents. 
Appendix 2. The Distribution of DV Concept-Units by the Categories - Pivotal and Comprehensive Codes - with Excerpts from the Interviews ${ }^{9}$

\begin{tabular}{|c|c|c|}
\hline $\begin{array}{l}\text { Concepts } \\
\text { (supporting codes) }\end{array}$ & $\begin{array}{l}\text { Categories } \\
\text { (pivotal codes) }\end{array}$ & $\begin{array}{l}\text { Categories } \\
\text { (comprehensive } \\
\text { codes) }\end{array}$ \\
\hline $\begin{array}{l}\text { Female ridicule for fear of coronavirus, the } \\
\text { husband's obscenities and verbal insults; } \\
\text { Forcing and pressuring a woman to have } \\
\text { sex and not being accepted by a woman } \\
\text { for fear of coronavirus; } \\
\text { Insults with corona virus content, constant } \\
\text { and unreasonable anger at a woman's } \\
\text { normal behavior at home; } \\
\text { Husband's objection and unreasonable } \\
\text { insults; } \\
\text { Threat of violence and beatings by men, } \\
\text { Threatening a woman with divorce; } \\
\text { Reminder of previous family disputes by } \\
\text { the man. }\end{array}$ & $\begin{array}{l}\text { Cursing, humiliating, } \\
\text { and threatening } \\
\text { woman; } \\
\text { insulting the spouse's } \\
\text { family. }\end{array}$ & $\begin{array}{l}\text { Humiliation and } \\
\text { verbal abuse. }\end{array}$ \\
\hline
\end{tabular}

Negar, 47: We have been using the pocket (savings) for two months now, sometimes I tell her (husband) why don't you go to work? He got angry and shouted angrily, which idiot goes out to work in coronavirus conditions??? I tell him what will you do if the coronavirus runs out? He says I will not go to work until you die of hunger. I like to do this (a kind of stubbornness of the husband and psychological harassment of the wife). In a way, I will ruin you so that you do not command or forbid me anymore.

Neda, 28 years old without children. Her husband has a market josb and a diploma (low). My husband is a carefree person. Ever since the coronavirus was born, he has always ridiculed me for being afraid of the disease. Coronavirus has become a means of entertainment for my husband to laugh at me and make fun of me.

Nazanin, 30, has two children. She talks about the natural process of doing housework, which causes her husband to get angry and find fault. She says: My husband complains about the housework and how it is done because of quarantine and constant presence in the house. He tells me "you are noisy, and you are boring". It is as if staying at home makes him nervous and he pours this anger on me.

Sanaz, 39, says her differences with her spouse have intensified: We already had a disagreement and it was not that big. Now that he (her husband) has to stay at home, there

9. Original wording, and abruptions in speech were preserved. 
are many more dissputes and he constantly threatens me with divorce, because he knows that I am afraid of divorce.

Fatemeh, 38, complains about her husband's constant presence in the house: Corona has become an incurable pain for our lives. The misfortunes began when the coronavirus came. What can a man who stays at home have but a headache? Men, if they stay home longer than a certain time, or if they are not tired and wake up in the morning, do not know how to talk to their wives properly, help you and have nothing for you but trouble.

\begin{tabular}{l|l|l}
\hline \hline $\begin{array}{l}\text { Preference of friends over women and } \\
\text { children by men; lack of hygiene by the } \\
\text { man as a weapon to harass the woman; } \\
\text { observance of hygienic conditions } \\
\text { provided that the woman is completely } \\
\text { obedient at home; increased feelings of } \\
\begin{array}{l}\text { abuse and misbehavior; looking at your } \\
\text { spouse like a servant; the demand of } \\
\text { obedience and servitude; the man's lordly } \\
\text { encounter with his wife at home. }\end{array}\end{array}$ & $\begin{array}{l}\text { Indifference and } \\
\text { ignoring women; } \\
\text { obedience; } \\
\text { abuse. }\end{array}$ & $\begin{array}{l}\text { Psychological } \\
\text { violence. }\end{array}$ \\
\hline Robabeh:
\end{tabular}

Robabeh: My husband does not wear a mask at all. I give him a mask, he puts it in his pocket. Does not use and is carefree. While he is shopping, I tell him to put on the mask, he tells me to go out of the house and put on the mask. But I look at him slowly and see that he is not wearing a mask. When he returns, we will fight. I tell him are you kidding me? Why are you lying?! I said why don't you use gloves? he said I don't have gloves. I gave him my gloves, once I did not see him use gloves. It made me crazy and rebellious.

Samaneh: With regret for being alone and being forced to stay at home, she says: Nader (husband) spends all his time outside the house and having fun with his friends, and it has become a good excuse for him that he is a coronavirus and he will not let me. Let me go out with him. He lies to me that he goes out to buy a house, but I know he is having fun with his friends without paying any attention to the dangers of coronavirus.

Nastaran says that her husband wants her to become a completely submissive woman: He wants me to do everything she tells him to do. He has taken time off from work and stayed at home for me to serve him. If I had known him like this, I would not have married him. Before this disease (coronavirus) he went to work and came home, he did not have much contact with me and he got tired and slept. This staying at home made me know him better. Incidentally, Coronavirus was very lucky for me because it made me know him and know how violent and selfish this person is. 


\begin{tabular}{|c|c|c|}
\hline $\begin{array}{l}\text { The intensification of restrictions on a } \\
\text { woman's relationship with her friends } \\
\text { by her husband; interrupting a woman's } \\
\text { relationship with her friends and } \\
\text { acquaintances; controlling women's } \\
\text { activities in cyberspace with the presence } \\
\text { of more men at home during the } \\
\text { quarantine period; female house arrest } \\
\text { and shopping by a man; does not allow } \\
\text { the woman to leave the house even for a } \\
\text { few minutes; Coronavirus is a good excuse } \\
\text { for male domination at home. }\end{array}$ & $\begin{array}{l}\text { Male overlordship, } \\
\text { control and } \\
\text { repression; restrictions } \\
\text { and supervision of } \\
\text { women; } \\
\text { the intensification } \\
\text { of restrictions on a } \\
\text { woman's relationship } \\
\text { with her friends by } \\
\text { her husband; inter- } \\
\text { rupting a woman's } \\
\text { relationship with her } \\
\text { friends and acquain- } \\
\text { tances. }\end{array}$ & $\begin{array}{l}\text { Performing male } \\
\text { domination and } \\
\text { restrictions on } \\
\text { women. }\end{array}$ \\
\hline
\end{tabular}

Negar: He does not allow me to leave the house. In the evenings he goes by himself, buys bread and supplies, and returns. Well, In this way, he can leave the house for at least a few hours and be in a better mood. He does not allow me to even walk in a secluded place under the pretext that the disease is dangerous. This is an excuse to bully him. I'm getting depressed. I can easily understand that my nerves are sick. I rotted.

Sogand speaks of restricting her from her friends: My husband is a shopkeeper in the market. That's why he has to go to the store in the morning and in the afternoon. Corona caused us to close the shop for about 2 weeks and stay at home together during the quarantine. When my husband went to his shop, I had a group with my friends, and we went for a walk and had fun. He has been monitoring me since he had to stay at home. He does not allow me to go out with my friends and complains about why I have been leaving the house so much before. He picks up my phone and is suspicious. Because he is unemployed, he is in prison-like a prison guard, he is constantly paying attention to me and does not even let me leave the house.

Neda is a newly married woman who talks about giving orders to her husband and severely restricting him at home: My husband is afraid of everything. He thinks he is wiser than me and does not get the Coronavirus, and he does all the work outside the house, including his own purchase, and he told me that I have no right to leave the house. I do not dare to leave the house. Although this seems like a sacrifice, I need to go out with him for at least a few minutes, and he won't let me. I have been captured and because he has some harsh morals, if I argue with him, I am sure he will fight.

Golnaz says that her husband is suspicious and has excuses for monitoring the mobile phone: Hamid did not doubt me before and he trusted me a lot. Ever since he was forced to stay home because of the coronavirus, he has always had negative thoughts. He constantly 
secretly picks up my phone and checks my Instagram and Telegram pages. He even once told me directly not to chat with anyone (a stranger boy) one day and I did not know. I was so upset that I told my family, and he would apologize for not being in a balanced mood due to the epidemic. Staying at home has made him think very negatively and slander me for no reason.

\begin{tabular}{|l|l|l|}
\hline \hline $\begin{array}{l}\text { Slapping his wife; throwing a cell phone at } \\
\text { a spouse; bruising the wife's hand. }\end{array}$ & $\begin{array}{l}\text { Violent quarrel, } \\
\text { mayhem with women. }\end{array}$ & Physical violence. \\
\hline
\end{tabular}

Susan, a 29-year-old woman who got married at the age of 19, and exposes her husband's physical violence during the coronavirus, says: For fear of the coronavirus, he constantly tells me to make tea, make boiling water and herbal tea, he does not help me in anything. I just did not do this for him for one day, he hit me hard on the back with a teapot of tea and said that he was so awkward that you could not make tea, you deliberately wanted me to die. Damn this coronavirus, I have been beaten twice by my husband because he was obsessed with cleaning, I washed the fruit once and he is very insistent that I wash all the tools and fruits thoroughly with detergent, some fruits like grapes must not be washed with dishwashing detergent, Because it spoils the fruit, I do not know what problem he had in washing the grape, which pulled my hair and said how much I emphasize to you, wash the fruits carefully, you probably want to kill us.

Because alcohol is expensive, we have to disinfect equipment and handles with ordinary, inexpensive detergents, says Sarah about disinfecting door handles and shoes. I did not know that this detergent would damage the shoes, and I usually disinfected them for fear that the shoes would become contaminated. One morning when I was asleep and my husband saw his shoes, his shoes were broken and the soles of his shoes were torn off. He woke me up with a kick and slapped me gently. He said, "Do you not have the wisdom to ruin your shoes easily?" I had just bought these shoes. You disinfect your whole life every day with obsessive-compulsive disorder and the bad smell of this detergent causes us headaches every day.

\begin{tabular}{|l|l|l|}
\hline \hline $\begin{array}{l}\text { Male discrimination on the basis of social } \\
\text { distance between one's family and one's } \\
\text { spouse's family; the previous disputes } \\
\text { over the families of the parties are } \\
\text { highlighted; cutting ties with the family } \\
\text { and leaving the woman alone to take } \\
\text { care of the children; transferring male } \\
\text { and female conflicts to the children in the } \\
\text { family; the husband's violence against } \\
\text { children. }\end{array}$ & $\begin{array}{l}\text { family relationships; } \\
\text { the husband's violence } \\
\text { against children. }\end{array}$ & $\begin{array}{l}\text { Challenging the } \\
\text { focus on the } \\
\text { spouse's family }\end{array}$ \\
& & \\
\hline
\end{tabular}


Nazi: Before the outbreak of the coronavirus, I could easily take care of the children and leave them at my mother's house, and I could easily go to work myself. I can no longer do this. I am afraid that my children will transmit the Coronavirus to my elderly mother and father. Instead of working with me, my husband constantly argues with me to stay home and take care of the children and not go to work. He always wanted an excuse to prevent me from working. Now, this coronavirus has become a strong excuse for him to ask me to stop working and do housekeeping.

Mobina describes a very bitter incident that was the source of her intense disagreement with her husband: I am very aware of the coronavirus and I wear a mask wherever I go. We went to my mother-in-law's house for a party one night. We both wore masks. My mother-in-law took a corona three days after we went home. Thank God he is better. My husband slandered me without any reason or evidence that I must have transmitted the virus to his mother because I already had a cold and did not really have the Coronavirus. For this reason, he blamed me for his mother's illness, and I argued with him, and he beat me severely.

\begin{tabular}{l|l|l|}
\hline \hline The man's lack of cooperation in domestic \\
affairs, despite not going to work; the \\
man's lack of cooperation in handling the \\
$\begin{array}{l}\text { children's homework; increasing female } \\
\text { household chores due to food disinfection } \\
\text { and healthier food preparation; } \\
\text { challenges due to spouse irresponsibility } \\
\text { and selfishness. }\end{array}$ & $\begin{array}{l}\text { irresponsibility in } \\
\text { housework; men's } \\
\text { lack of cooperation in } \\
\text { homework. }\end{array}$ & $\begin{array}{l}\text { Performing men's } \\
\text { irresponsibility } \\
\text { and carelessness } \\
\text { at home. }\end{array}$ \\
\hline
\end{tabular}

Negar: At the moment, you have to disinfect every purchase you make according to the order of health officials. As usual, I have to alcoholize and disinfect everything alone and without help. Although my husband (Navid) is more sensitive to health than I am, he himself does not do anything, he only orders Negar to wash it and Negar to wash it. It even goes so far as to buy chips and packaged food for the kids, I have to disinfect with alcohol. And he does not do this small thing. Disinfecting green fruits is a hassle. Previously, we easily washed the fruits with water and put them in the refrigerator. Now we have to wash the fruits and vegetables or dishwashing liquid, then rinse them and leave them in the refrigerator.

Nazanin: In this situation and the epidemic of the virus, we have to disinfect everything in life. So much (Vitex) (name cheap and harmful detergent) to the door handles and stairs, shoes, cell phones and everything we use that my other lungs are damaged and I cough. Babak (her husband) does not help me even once and I do everything alone. He is very carefree and is not afraid of anything. He tells you that you are very cowardly, so clean everything yourself. It has nothing to do with me. In addition, sometimes he argues with me that the house smells of detergent. 
Sara has similar views with Nazanin: Instead of helping me and being cautious, $M r$. (husband) causes me torment and constantly complains about why you wash the fruits so much, why you disinfect the sink so much, On the one hand, I have to work at home and worry about my own health and that of my child, and on the other hand, I have to endure my husband's Murmuring and complaining for hygiene. I really can no longer.

The lack of hygiene by men during the coronavirus; the failure to follow hygiene tips when shopping outdoors and excessive stress on the spouse due to the negligence of the husband; the failure of the man to observing social distance during the quarantine period;

\begin{tabular}{l|l}
$\begin{array}{l}\text { Ignoring the dangers } \\
\text { of coronavirus by the } \\
\text { husband; }\end{array}$ & $\begin{array}{l}\text { Disputes over the } \\
\text { observance of } \\
\text { men neglect to } \\
\text { observe health tips during } \\
\text { the lockdown } \\
\text { and argue with their } \\
\text { spouse. }\end{array}$ \\
\hline
\end{tabular}

Mina: My husband does not take good care of his hygiene. When he goes shopping, he goes out and comes back, I have a lot of stress. He touches everything in the house. It does not put bread in the cloth. Take the purchased plastic and utensils inside the house if those plastics are very dirty and contaminated. When he comes home, the child goes to him and hugs the child without changing his clothes and washing his hands, all these things are driving me crazy. I have to be careful that he comes home, I put his belongings somewhere so that the child does not touch them and force him to observe hygiene.

Fatemeh arguing with her husband: We went shopping together for our needs in the market because of her husband's negligence. First, he was hardly content to wear a mask. I wear two masks wherever I go and I am very careful. He was picking fruit from the box and put his hand to his nose as he picked Portugal. I warned him, but he insulted me in front of the seller and I was very embarrassed.

\begin{tabular}{|c|c|c|}
\hline $\begin{array}{l}\text { Woman arguing with her husband over } \\
\text { not praying for Coronavirus to disappear; } \\
\text { feeling closer to God by the woman and } \\
\text { the man mocking her; increased religious } \\
\text { differences. }\end{array}$ & $\begin{array}{l}\text { Dual-God } \\
\text { believing couple. }\end{array}$ & $\begin{array}{l}\text { Intensification of } \\
\text { religious conflicts } \\
\text { during the } \\
\text { period of home } \\
\text { lockdown. }\end{array}$ \\
\hline
\end{tabular}

Samaneh: I believe in God a lot and I pray a lot, especially during the Viruscrona era, because I believe that God can take care of me and my family. But Saeed is not very important to him and he mocks me that your prayers are useless.

Nahid: My husband is very religious. During this quarantine period, he argues with me a lot about why I do not pray as much as he does. He used to argue many times that you do not pray at all. Now in Corona, he expects me to vow and need from morning till night. He intervenes constantly and tells me that because you do not have much faith and do not pray, we will get the Coronavirus. 


\begin{tabular}{|l|l|l|}
\hline \hline $\begin{array}{l}\text { Increased economic disputes between } \\
\text { husband and wife due to male }\end{array}$ & $\begin{array}{l}\text { Reducing women's } \\
\text { economic authority; } \\
\text { unemployment during the quarantine } \\
\text { period; male domination due to the } \\
\text { economic dependence of women and } \\
\text { children on men; increased anger and } \\
\text { resentment of the man due to financial } \\
\text { pressure and its transfer to the spouse; } \\
\text { pattern at home. }\end{array}$ & $\begin{array}{l}\text { Economic } \\
\text { challenges. }\end{array}$ \\
$\begin{array}{l}\text { woman and blaming her by her husband } \\
\text { for staying at home; the assignment of } \\
\text { home expenses management from the } \\
\text { woman to the man and arguing with } \\
\text { women for this reason; reducing women's } \\
\text { economic authority during the quarantine } \\
\text { period. }\end{array}$ & & \\
\hline
\end{tabular}

Sedighe: Coronavirus ruined our lives. My husband is Weekly peddling. Doesn't anyone think about how to pay for a family? I see we have no money, I get angry, I say something to him and he says something in response. We do not have a problem with each other, but since the coronavirus came and my husband could not work, he has become very nervous and angry. I can't even talk to him for five minutes and I'm scared. His morals have changed completely since the day he became unemployed.

Sanaz says that her husband is angry because of unemployment and this anger is dragged into the house: Due to quarantine, Manouchehr has not been able to go to work several times so far. He owns a small sandwich shop. He is angry because they Compulsory closure and say you should stay at home, and he pours this anger on me as if I am to blame for the situation.

Nazi, 34 years old and has one child: From the day the quarantine was imposed, the store manager told me that because the shop was closed, they could no longer pay us, and I lost my job. My husband now uses this as an excuse to say that I am a free eater and they pay for the family alone, and he constantly puts his money on me.

\section{Appendix 3. Domestic Emotional/Mental Violence Concept-Units Featured by the COVID-19 Lockdown (Illustrated by the Excerpts from Interviews) ${ }^{10}$}

Feelings of sadness, depression, and routine life during the lockdown:

Mina: I was always very happy near the transition to the New Year, even though I had a lot of work to do, but this year it became a Coronavirus, and I was feeling tired even though 
I had not prepared myself for any travel or party. It is as if I did a lot of hard work! Two or three weeks before the New Year, I was in a state of despair at home. I was nervous. I was not motivated.

Increased feelings of loneliness in married women during the lockdown:

Mina: My husband was always self-involvement, sleep late at night and waking up early in the morning. It seems not to be at home, and I felt only this kid and me existed in this house. Only his body was here.

Doubled female stress (corona stress + the stress of lower personal sanitation by the man):

Mina: Early in the quarantine, my husband said that I have a few clients and I would go to work. I had stressed all time when he went out a few times and come back, I thought and asked myself he is currently in contact with several people. If anyone has a disease, what do I do? We have a small child. The baby's lungs are sensitive and if getting sick. What do I do? My husband does not consider personal sanitation. He does not put alcohol in his car and He does not pay attention to the mask and constantly loses it. This behavior has driven me to the brink of insanity.

\section{Decreased and reluctant sex:}

Golnaz: I am no longer in the mood. Now, who has the mood to give sexual services to her husband? They think about their goals in sex. Men only think about themselves in sex.

Nazanin: Before the coronavirus came, we did not have much sex. Now that the coronavirus has spread, my husband has no sexual desire for me and says we should not sleep too much together because it is dangerous. It is interesting that the man himself goes out of the house and is afraid of me while I am always at home and I do not go anywhere. Isn't this interesting to you.

Lack of cooperation of men in household affairs despite leaving their jobs:

Robabeh: Where was the help! My husband does not do anything at home. He used to go to work and say I was tired. Even now, despite being unemployed at home, he is used to being lazy. He is just napping. I have to do everything myself. He gives orders and always expects me to serve him. Only the gentleman should give the order and I should obey.

\section{Challenges of husband's irresponsibility and selfishness:}

Parisa: Saeed (my husband) always went in front of the house and stood or walked and came back and it did not matter to him at all that there was a coronavirus and it was very dangerous. I was arguing with him. I told him why do you go out? He said I was bored. I feel better when I go out. When he returned home, he often forgot to wash his hands. He does pay no attention to anything. So when he came to the house, I sprayed (disinfectant) 
everywhere to clean it. All parts of the house. And I had no right to tell him to take care of his personal hygiene.

\section{Lack of hygiene by men during the lockdown:}

Robabeh: He does not understand what hygiene is at all. It only bothers me. It is self-opinion and selfishness about observing human personal health, and this will cause us to argue and fight with each other so, that he will be persuaded to wash his hands. Sometimes he deceives me and only washes his hands with water and does not use sanitizing liquid. To deceive me, he shows me his wet hands and says, Look, I'm washed and cleaned, he is lying.

\section{Husband refrains from observing social distance at home during being ill:}

Robabeh: My husband had a cold. As a precaution against coronavirus, I had separated the dishes. But he did not care and ate in our food containers. I told him not to get too close to the children at the moment, maybe you have coronavirus, he was stubborn and deliberately approached the children and said that the children do not get coronavirus.

Reminders of past family disputes by the man due to quarantine and long hours at home:

Robabeh: Since he was forced to stay at home due to quarantine, he only criticizes me, he has reminders of what differences he had with my father and brother before. When a man sits idle and stays at home, he to bite like a dog (A term used to describe that her husband is constantly harassing her).

Increased economic disputes between husband and wife due to male unemployment during the lockdown:

Nahid: You know that my husband's job is photography. Under normal circumstances, he did not have many customers, he was going bankrupt. Now that Coronavirus has arrived and is closed everywhere, things have gotten worse It is not clear how we should pay the bank loan installments. I am more worried and my husband is very carefree. It is my right to grumble and argue with him because we have no money to support the family.

Nazi: If I just argue with him for a while, he will not pay for the house, he will not pay for the children. He says that it is enough that no matter how much I pay for the house, your tongue is outstretched (correction means that you have become obscene and Peruvian). Now we have to be silent and say nothing. The coronavirus also became an excuse for not giving me any more money.

Severe restrictions on a woman's relationship with her family and friends:

Sara: Coronavirus has become my husband's excuse for taking everything from me. I do not even dare to call my man, he says how often do you call. Do you know how much money is charged? I used to be able to walk down the alley with the lady next door, but now she won't let me. He says it is a coronavirus and you have no right to go out. 
Control of female activities in cyberspace with the more male presence at home during the lockdown:

Fatemeh: You know what I mean, something that is logical does not upset anyone. For example, if I were a woman who did not cook, I would make him angry and not do my homework, He had the right to restrict me and tell me not to go out. When I do all this work, why not let me go out? Why not let me talk to someone on the phone? Supervised at home and as if he is my control agent, I can not send a message in Telegram, I am not allowed to send a message in WhatsApp. Why does he take what is my right from me? I do obey him because there should always be fights. At the same interview that you wanted to do, you saw how many times you called and said I could not speak because I was afraid, he would slander me.

Male discrimination in the field of social distance between his family and his wife's family:

Negar: During the quarantine, it was decided that none of us should go to the family home and spend the holidays at home. He told me that you are not allowed to go to your family home. While he was visiting his family every day alone under the pretext of shopping, and I realized this. There were fights between us and insults were exchanged between us. He talks irrationally. He said that my mother's house was close, that I had gone and that I had not entered the house. I also said that I will not go inside my mother's house, but I want to see her.

Soodabeh: My husband even wanted to go to his father's house at a time when the coronavirus outbreak has increased and is closed everywhere. He invites his brothers to our house. How does he have the right to do this, but I have no right to do this at all? It seems that only he loves his family and I do not love my family. He is very selfish and pushy.

\section{Acknowledgements}

We are very grateful to our research participants - the women-respondents - for their sincere cooperation. Despite the difficult domestic conditions and the fear of the COVID-19 pandemic as well as the experience of domestic violence during the lockdown, they have responded to our request for a lengthy interview. We appreciate it very much.

\section{Credit Authorship Contribution Statement}

Svetlana Bankovskaya: Conceptualization, methodology, writing of the final draft, writing of the review and editing.

Javad Maddahi: Conceptualization, methodology, data analysis, data transcription, writing the original draft, translation from Farsi into English.

Tahereh Lotfi Khachki: Sampling, interviewing, recording interviews, transcribing, writing of the original draft, translation from Farsi into English. 


\section{References}

Aldiabat K. M., Le Navenec C. (2018) Data Saturation: The Mysterious Step in Grounded Theory Method. The Qualitative Report, vol. 23, no 1, pp. 245-261.

Amanoolahifard A., Mohseni A., Teimori J., Mokhtarpour M., Gholami A., Moghimi M. (2008) The Study of Abuse against Women by Their Husbands in the city of Ahvaz. The Third National Congress of Family Pathology, Tehran. (In Persian)

Bowen G. A. (2008) Naturalistic Inquiry and the Saturation Concept: A Research Note. Qualitative Research, vol. 8, no 1, pp. 137-152.

Charmaz K. (2006) Constructing Grounded Theory: A Practical Guide through Qualitative Analysis, London: Sage.

Derrida J. (1994) Spectres of Marx: The State of the Debt, the Work of Mourning and the New International, New York: Routledge.

Flick U., von Kardoff E., Steinke I. (2004) A Companion to Qualitative Research, London: Sage.

Galtung J. (1969) Violence, Peace, and Peace Research. Journal of Peace Research, vol. 6, no 3, pp. 167-191.

Galtung J. (1990) Cultural Violence. Journal of Peace Research, vol. 27, no 3, pp. 291-305.

Ghahari S., Mazandarani S., Khalian A. R., Zarghami M. (2008) Spousal Abuse in Sari, Iran. Iranian Journal of Psychiatry and Behavioral Sciences, vol. 2, no 1, pp. 31-36.

Ghazizadeh A. (2005) Domestic Violence: A Cross-sectional Study in an Iranian City. Eastern Mediterranean Health Journal, vol. 11, no 5-6, 880-887.

Glaser B. G. (2014) Choosing Grounded Theory. The Grounded Theory Review, vol. 13, no 2, pp. 3-19.

Glaser B., Strauss A. (1967) The Discovery of Grounded Theory: Strategies for Qualitative Research, Mill Valley: Sociology Press.

Guest G., Bunce A., Johnson L. (2006) How Many Interviews are Anough? An Experiment with Data Saturation and Variability. Field Methods, vol. 18, no 1, pp. 59-82.

Hennink M., Kaiser B. N., Marconi V. C. (2016) Code Saturation versus Meaning Saturation: How Many Interviews are Enough? Qualitative Health Research, vol. 27 no 4, pp. $1-18$.

Maghsoudi S., Yarinasab F., Ebrahimi F. (2015) Investigating Factors Influencing Domestic Violence against Women (Case Study: City of Kerman). Quarterly Journal of Social Development, vol. 9, no 3, pp. 53-78.

Malek Afzali H. (2004) Study of Domestic Violence Involving Women in the City of Isfahan. Medical Science Journal of Islamic Azad University, Tehran Medical Branch, vol. 14, no 2, pp. 62-67.

Morse J. M., Richards L. (2002) Readme First for a User's Guide to Qualitative Methods, London: Sage.

Morse J. M. (2004) Theoretical Saturation. The Sage Encyclopedia of Social Science Research Methods (eds. M. S. Lewis-Beck, A. Bryman, T. F. Liao.), London: Sage.

Morse J. M. (2015) Critical Analysis of Strategies for Determining Rigor in Qualitative Inquiry. Qualitative Health Research, vol. 25, no 9, pp. 1212-1222. 
Mousavi S. M., Eshagian A. (2005) Wife abuse in Esfahan, Islamic Republic of Iran, 2002. Eastern Mediterranean Health Journal, vol. 11, no 5-6, pp. 860-869.

O’Reilly M., Parker N. (2012) "Unsatisfactory Saturation": A Critical Exploration of the Notion of Saturated Sample Sizes in Qualitative Research. Qualitative Research, vol. 13, no 2, pp. 190-197.

Ostvar Namaghi (2006) Immunity among Iranian EFL Teachers: Sources, Impacts, and the Developmental Path. Available at: https://civilica.com/doc/1158924 (accessed 15 September 2021).

Rahmatian A. A., Hosseini S. A. A. (2015) Domestic Abuse in Behshahr, Iran. Iranian Journal of Psychiatry and Behavioral Sciences, vol. 9, no 4, pp. e179o.

Rasoulian M., Jalali A. H., Habib S., Molavi Nojomi M., Ghanbari Jolfaei A., Bolhari J. (2017) Risk Factors of Domestic Violence in Iran. Iranian Journal of Psychiatry and Behavioral Sciences, vol. 11, no 1, pp. e4280.

Statista (2021) Coronavirus (COVID-19) Deaths Worldwide per One Million Population as of December 13, 2021, by Country. Available at: https://www.statista.com/ statistics/1104709/coronavirus-deaths-worldwide-per-million-inhabitants/ (accessed 13 December 2021).

Strauss A., Corbin J. (1994) Grounded Theory Methodology: An Overview. Handbook of Qualitative Research (eds. K. D. Norman, S. L. Y. Vannaeds), London: Sage, pp. 22-23.

Tourangeau R., Yan T. (2007) Sensitive Questions in Surveys. Psychological Bulletin, vol. 133 , no 5 , pp. $859-883$.

UN Women (2021a) Press Release: Devastatingly Pervasive: 1 in 3 Women Globally Experience Violence. Available at: https://www.unwomen.org/en/news/stories/2021/3/ press-release-1-in-3-women-globally-experience-violence (accessed 13 December 2021).

UN Women (2021b) Global Database on Violence against Women. Available at: https:// evaw-global-database.unwomen.org/en/countries/asia/iran-islamic-republic-of\#2 (accessed 13 December 2021).

UN Women (2021c) COVID-19 and Violence against Women: What the Data Tells Us. Available at: https://www.unwomen.org/en/news-stories/feature-story/2021/11/ COVID-19-and-violence-against-women-what-the-data-tells-us (accessedd 24 November 2021).

WHO (2021) World Health Statistics 2021: A Visual Summary. Available at: https://www. who.int/data/stories/world-health-statistics-2021-a-visual-summary (accessed 13 December 2021).

Zamani-Moghadam M., Hasanvandi S. (2019) A Qualitative Study of Domestic Violence Against Housewives in Khorramabad. Quarterly Journal of Women and Society, vol. 10, no 39, pp. 145-170.

Zare Shahabadi A., Nadarpoor Y. (2016) An Investigation into the Relationship between Patriarchy and Violence against Women in Koohdasht. Social Welfare Quaterly, vol. 16, no 6o, pp. 61-86. 


\section{От изоляции к насилию: изменения домашней среды в иранской семье в условиях COVID-19}

\section{Светлана Баньковская}

Кандидат философских наук, PhD, профессор, ведущий научный сотрудник, Центр фундаментальной социологии, Национальный исследовательский университет «Высшая школа экономики»

Адрес: ул. Мясницкая, д. 20, г. Москва, Российская Федерация 101000

E-mail: sbankovskaya@hse.ru

\section{Джавад Маддахи}

$\mathrm{PhD}$, Университет Харазми

Адрес: No. 43, Shahid Mofatteh Ave., Tehran, Iran

E-mail: std_Javad.Maddahi@khu.ac.ir

\section{Тахере Лотфи Хачаки}

$\mathrm{PhD}$, Университет Фердоуси в Мешхеде

Адрес: Azadi Square, Mashhad, Razavi Khorasan Province, Iran

E-mail: ta_lo249@mail.um.ac.ir

Домашнее насилие стало глобальной социальной проблемой во время вспышки пандемии COVID-19, особенно в период изоляции. Насилие стало проблемой и для некоторых иранских семей. В статье представлены данные, полученные в ходе полуструктурированных интервью, и сделаны некоторые (пока предварительные) выводы о характере изменений в режиме отношений традиционной иранской семьи, включая усиление домашнего насилия и преобладание насилия ментального/эмоционального, а также изменения в восприятии своего «дома» в новых условиях изоляции и насилия. Все многообразие видов насилия отчасти уже хорошо классифицировано, например, символическое, физическое и экономическое. Другие проявления домашнего насилия, такие как унижение и вербальное насилие, усиление ограничений (или даже запрет) на отношения женщины с друзьями и знакомыми, насилие мужа над детьми, споры о соблюдении санитарных норм во время изоляции, усиление религиозных конфликтов в период домашнего карантина и др., требуют более пристального изучения и интерпретации. Как теоретико-ориентированное исследование, эта работа показывает взаимосвязь различных видов насилия между собой, в том числе, специфичных для периода пандемии - самонасилия и самоизоляции, - их трансформации в эмоциональное насилие, которое обусловливает модификацию «дома» в гетеротопичное (амбивалентное) пространство - не только «свое» пространство, «убежище», но и опасное место, враждебная среда.

Ключевые слова: домашнее насилие против женщины, изоляция в период эпидемии, восприятие «дома», эмоциональное насилие 